This document is the Accepted Manuscript version of a Published Work that appeared in final form in: Organometallics 2016, 35, 14, 2378-2383, copyright @ American Chemical Society after peer review and technical editing by the publisher.

To access the final edited and published work see: https://doi.org/10.1021/acs.organomet.6b00380

\title{
Synthesis and Structure of Bis(diphenylphosphinimino)methanide and Bis(diphenylphosphinimino)methanediide Beryllium Complexes.
}

\author{
Melike Bayram, Dominik Naglav, Christoph Wölper, Stephan Schulz* \\ Institute of Inorganic Chemistry, University of Duisburg-Essen, 45117 Essen, Germany. E-mail: stephan.schulz@uni-due.de. \\ Supporting Information Placeholder
}

\begin{abstract}
Reactions of $\mathrm{BeEt}_{2}$ with bis(diphenylphosphinimino)methanes $\mathrm{H}_{2} \mathrm{C}\left[\mathrm{PPh}_{2} \mathrm{NR}_{2}\right.$ yielded the first bis(diphenylphosphinimino)methanide and bis(diphenylphosphinimino)methanediide beryllium complexes $\left[\mathrm{CH}\left(\mathrm{PPh}_{2} \mathrm{~N}-2,6-i-\right.\right.$ $\left.\left.\mathrm{Pr}_{2} \mathrm{C}_{6} \mathrm{H}_{3}\right)_{2}\right]$ BeEt 1, $\left[\mathrm{C}\left(\mathrm{PPh}_{2} \mathrm{NSiMe}_{3}\right)_{2}\right](\mathrm{BeEt})_{2} \mathbf{2}$ and $\left[\mathrm{C}\left(\mathrm{PPh}_{2} \mathrm{NPh}\right)_{2}\right](\mathrm{BeEt})_{2} \mathbf{3}$, respectively. $\mathbf{1} \mathbf{3}$ were characterized by multinuclear NMR and IR spectroscopy as well a single crystal X-ray diffraction.
\end{abstract}

\section{INTRODUCTION}

The chemistry of beryllium differs significantly from that of the heavier group 2 metals as well as from group 12 metals in particular from the well established $\mathrm{Mg}$ and $\mathrm{Zn}$ chemistry due to the small size of the Be atom and its high Lewis acidity. Even though the high toxicity of beryllium and beryllium compounds hampered Be compounds to become widely applied, ${ }^{[1]}$ beryllium chemistry has received growing interest within the last decade. ${ }^{[2]}$ In addition to well established Cpsubstituted beryllium complexes, which have been initially reported by E.O. Fischer in $1959^{[3]}$ and whose structures in the solid state, ${ }^{[4]}$ in solution ${ }^{[4,5]}$ and in the gas phase, ${ }^{[6]}$ respectively, have been studied experimentally and by quantum chemical calculations, ${ }^{[7]}$ homoleptic and heteroleptic complexes with sterically demanding substituents have been investigated. Power et al. reported on Be complexes containing terphenyl ligands, ${ }^{[8]}$ while the synthesis, structure and reactivity of basestabilized beryllium complexes, in particular NHCcoordinated beryllium compounds, ${ }^{\left[{ }^{[]}\right.}$was studied by several groups. In addition, the search for isolable Be(I) compounds as well as highly electrophilic cationic complexes, for which quantum chemical calculations have become very important ${ }^{[10]}$ has pushed this chemistry in the last years.

Bidentate and tridentate $\mathrm{N}$-chelating organic substituents such as amidinates, guanidinates, $\beta$-diketiminate, bis(phosphinimino)methanide or tris(pyrazolyl)borate have been established for the synthesis of stable $\mathrm{Mg}(\mathrm{I})$ and $\mathrm{Zn}(\mathrm{I})$ complexes in the past. ${ }^{[11]}$ As a consequence, heteroleptic beryllium complexes containing amidinate, ${ }^{[12]} \beta$-diketiminate ${ }^{[13]}$ and tris(pyrazolyl)borate substituents, ${ }^{[14]}$ which are potential precursors for the corresponding $\mathrm{Be}(\mathrm{I})$ complexes, have been synthesized and structurally characterized, whereas bis(iminophosphorano)methanide beryllium complexes are unknown, to date. Unfortunately, to the best of our knowledge, all complexes failed for the synthesis of the desired monovalent beryllium complexes.
Due to our general interest in main group metal chemistry, we started only recently our research on beryllium compounds and reported on the synthesis of several heteroleptic and homoleptic beryllium complexes containing $\mathrm{Cp}^{*}{ }^{[15]}$ tris(pyrazolyl)borate ${ }^{[16]}$ as well as amide substituents. ${ }^{[17]} \mathrm{We}$ herein report on reactions of $\mathrm{BeEt}_{2}$ with bis(diphenylphosphinimino)methanes of the general type $\mathrm{H}_{2} \mathrm{C}\left[\mathrm{PPh}_{2} \mathrm{NR}\right]_{2}$ in different molar ratios, yielding the first mononuclear bis(diphenylphosphinimino)methanide as well as dinuclear bis(diphenylphosphinimino)methanediide beryllium complexes.

\section{RESULTS AND DISCUSSION}

Equimolar reactions of $\mathrm{H}_{2} \mathrm{C}\left[\mathrm{PPh}_{2} \mathrm{NR}\right]_{2}\left(\mathrm{R}=\mathrm{SiMe}_{3}, \mathrm{Ph}, 2,6-\right.$ $i$ - $\mathrm{Pr}_{2} \mathrm{C}_{6} \mathrm{H}_{3}$ ) with $\mathrm{BeEt}_{2}$ at $-78{ }^{\circ} \mathrm{C}$ occurred with elimination of ethane as was shown by in situ ${ }^{1} \mathrm{H}$ NMR spectroscopy (scheme $1)$.
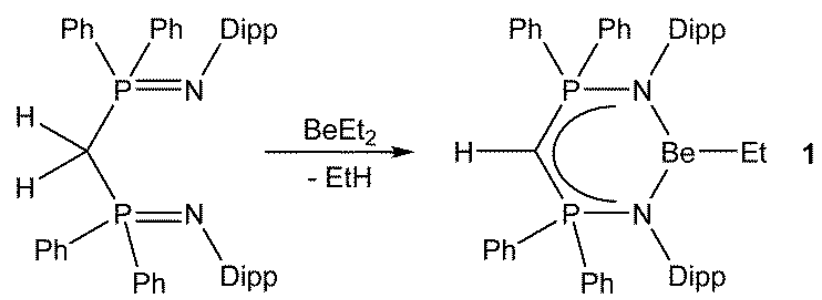

Scheme 1. Synthesis of 1 .

Unfortunately, only the reaction with $\mathrm{H}_{2} \mathrm{C}\left(\mathrm{PPh}_{2} \mathrm{~N}-2,6-i\right.$ $\left.\mathrm{Pr}_{2} \mathrm{C}_{6} \mathrm{H}_{3}\right)_{2}$ resulted in the quantitative formation of $\left[\mathrm{CH}\left(\mathrm{PPh}_{2} \mathrm{~N}-2,6-i-\mathrm{Pr}_{2} \mathrm{C}_{6} \mathrm{H}_{3}\right)_{2}\right] \mathrm{BeEt} \mathbf{1}$, which is a stable compound at ambient temperature in solution and in the solid state. In contrast, reactions of $\mathrm{BeEt}_{2}$ with $\mathrm{H}_{2} \mathrm{C}\left[\mathrm{PPh}_{2} \mathrm{NR}\right]_{2}$ ( $\mathrm{R}=$ $\left.\mathrm{SiMe}_{3}, \mathrm{Ph}\right)$ in different molar ratios $(2: 1,1: 1,1: 2)$ without exception gave mixtures of the expected bis(diphenylphosphinimino)methanide complexes $\left[\mathrm{CH}\left(\mathrm{PPh}_{2} \mathrm{NSiMe}_{3}\right)_{2}\right] \mathrm{BeEt}$ and $\left[\mathrm{CH}\left(\mathrm{PPh}_{2} \mathrm{NPh}\right)_{2}\right] \mathrm{BeEt}$, respec- 
tively, which were clearly identified in in situ ${ }^{1} \mathrm{H}$ NMR spectroscopy studies, as well as non-reacted $\mathrm{H}_{2} \mathrm{C}\left[\mathrm{PPh}_{2} \mathrm{NR}\right]_{2}$ and insoluble precipitates. Filtering off the precipitates gave clear solutions, which were found to decompose at ambient temperature within 1 to 2 days with subsequent formation of additional insoluble precipitate, indicating that the bis(diphenylphosphinimino)methanide beryllium complexes are thermally unstable. Addition of Lewis bases such as thf, acetonitrile or 4-dimethylaminopyridine (DMAP) had no stabilizing effect, indicating that $\mathbf{1}$ is not coordinated most likely as a result of steric effects. Comparable findings were reported for the analogous lithium complex $\left[\mathrm{CH}\left(\mathrm{PPh}_{2} \mathrm{~N}-2,6-i-\right.\right.$ $\left.\left.\mathrm{Pr}_{2} \mathrm{C}_{6} \mathrm{H}_{3}\right)_{2}\right] \mathrm{Li},{ }^{[28 \mathrm{e}]}$ which contains a two-coordinate lithium atom.

Compound $\mathbf{1}$ is soluble in toluene and THF, respectively. The ${ }^{1} \mathrm{H}$ NMR spectrum of $\mathbf{1}$ shows the resonances of the Be-Et group at -0.24 (methylene) and $0.50 \mathrm{ppm}$ (methyl) as well as the resonances of the bis(phosphinimino)methanide ligand including the backbone methine proton at $1.02 \mathrm{ppm}$ in the expected 1:1 molar ratio. The ${ }^{31} \mathrm{P}$ NMR spectra of $\mathbf{1}$ shows one sharp singlet at $29.95 \mathrm{ppm}$, which is shifted downfield compared to $\mathrm{H}_{2} \mathrm{C}\left[\mathrm{PPh}_{2} \mathrm{~N}-2,6-i-\mathrm{Pr}_{2} \mathrm{C}_{6} \mathrm{H}_{3}\right]_{2} \quad(-16.23 \mathrm{ppm})$. The IR spectra of 1 shows strong absorptions at $1238 \mathrm{~cm}^{-1}$, which can be ascribed to the $\mathrm{P}=\mathrm{N}$ stretching vibration.

Single crystals of $\mathbf{1}$ were obtained upon slow recrystallization from a solution of $\mathbf{1}$ in toluene at ambient temperature. 1 crystallizes in the orthorhombic space group $\mathrm{Pbca}$ with one independent molecule in the asymmetric unit. Figure 1 shows the solid state structure of 1 .

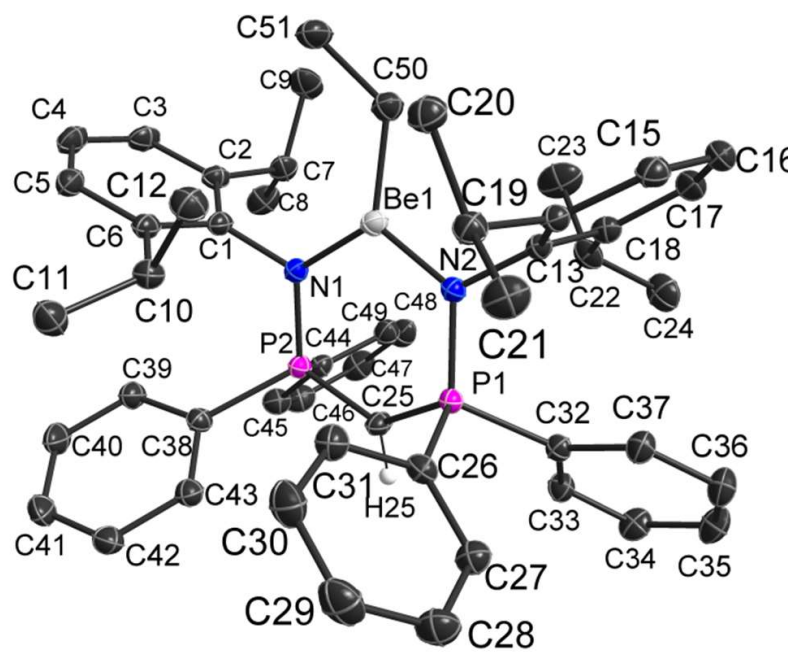

Figure 1. Solid state structure of $1 ; \mathrm{H}$ atoms are omitted for clarity, thermal ellipsoids are shown at $50 \%$ probability levels.

Compound 1 forms a monomeric complex in the solid state with trigonal-planar coordinated $\mathrm{Be}$ atoms (sum of the bond angles $\left.359.8(2)^{\circ}\right)$. A slightly distorted boat-type conformation was observed for the $\mathrm{CP}_{2} \mathrm{~N}_{2} \mathrm{Be}$ metallacycle as was previously reported for comparable zinc complexes of the general types LZnMe, ${ }^{[18]} \mathrm{L}_{2} \mathrm{Zn}_{2}$ and $\mathrm{Cp}{ }^{*} \mathrm{Zn}-\mathrm{ZnL}{ }^{\left[{ }^{[19]}\right.}$ The Be-N bond lengths in $1(1.654(2), 1.667(2) \AA)$ are comparable to those reported for $\beta$-diketiminate beryllium complexes, which were found to range from 1.58 to $1.70 \AA{ }^{[13]}$ while beryllium amidinate com- plexes containing four-membered $\mathrm{BeN}_{2} \mathrm{C}$ rings showed slightly elongated $\mathrm{Be}-\mathrm{N}$ bonds $(1.73-1.75 \AA),{ }^{[12]}$ most likely due to the increased ring strain compared to the six-membered $\mathrm{BeN}_{2} \mathrm{C}_{3}$ and $\mathrm{BeN}_{2} \mathrm{P}_{2} \mathrm{C}$ rings. The $\mathrm{P}-\mathrm{N}$ (1.6373(12), 1.6373(11) $\AA$ ) and P-C bond lengths (1.6954(14), 1.6874(14) $\AA$ ) as well as the endocyclic P-C-P (129.53(8) ${ }^{\circ}$ ) and C-P-N bond angles (109.26(6), 110.63(7) ${ }^{\circ}$ ) within the $\mathrm{CP}_{2} \mathrm{~N}_{2} \mathrm{Be}$ metallcycles of $\mathbf{1}$ are comparable to those reported for other bis(phosphinimino)methanide metal complexes. ${ }^{[20]}$ Compared to the endocyclic N-Be-N $\left(108-117^{\circ}\right)$ and C-N-Be $\left(117-123^{\circ}\right)$ bond angles observed in $\beta$-diketiminate beryllium complexes, the N-Be-N $\left(117.35(12)^{\circ}\right)$ and $\mathrm{P}-\mathrm{N}-\mathrm{Be}$ bond angles (124.16(10), 124.52(9) ${ }^{\circ}$ ) of $\mathbf{1}$ are relatively large (table 1).

Table 1. Selected bond lengths $[\AA]]$ and angles $\left[{ }^{\circ}\right]$ of 1 - 3 .

\begin{tabular}{|c|c|c|c|}
\hline & 1 & 2 & 3 \\
\hline $\mathrm{Be}-\mathrm{N}$ & $\begin{array}{l}1.654(2), \\
1.667(2)\end{array}$ & $\begin{array}{l}1.667(4), 1.667(4), \\
1.667(4), 1.671(4)\end{array}$ & $\begin{array}{l}1.649(3), \\
1.646(3)\end{array}$ \\
\hline N-P & $\begin{array}{l}1.6373(12), \\
1.6373(11)\end{array}$ & $\begin{array}{l}1.613(2), 1.626(2), \\
1.621(2), 1.611(2)\end{array}$ & $\begin{array}{l}1.6352(16), \\
1.6418(16)\end{array}$ \\
\hline $\mathrm{P}-\mathrm{C}_{\mathrm{bb}}{ }^{[\mathrm{a}]}$ & $\begin{array}{l}1.6954(14), \\
1.6874(14)\end{array}$ & $\begin{array}{l}1.715(3), 1.714(3), \\
1.709(3), 1.717(3)\end{array}$ & $\begin{array}{l}1.7143(19), \\
1.716(2)\end{array}$ \\
\hline $\mathrm{Be}-\mathrm{C}_{\mathrm{bb}}$ & - & $\begin{array}{l}1.827(5), 1.828(4), \\
1.817(5), 1.842(5)\end{array}$ & $\begin{array}{l}1.841(3) \\
1.827(3)\end{array}$ \\
\hline $\mathrm{Be}-\mathrm{C}_{\mathrm{et}}$ & $1.753(2)$ & $\begin{array}{l}1.708(5), 1.739(5), \\
1.720(5), 1.727(5)\end{array}$ & $\begin{array}{l}1.721(3), \\
1.729(3)\end{array}$ \\
\hline $\mathrm{Be} \cdots \mathrm{Be}$ & - & $2.688(6), 2.563(6)$ & $2.618(4)$ \\
\hline $\mathrm{P}-\mathrm{C}_{\mathrm{bb}}-\mathrm{P}$ & $129.53(8)$ & $\begin{array}{l}134.29(16), \\
133.54(17)\end{array}$ & $128.87(11)$ \\
\hline $\mathrm{P}-\mathrm{Cbb}-\mathrm{Be}$ & - & $\begin{array}{l}\text { 139.27(19), } \\
\text { 81.97(16), 80.20(16), } \\
123.41(18), 141.9(2), \\
82.13(16), 80.79(16), \\
123.99(19)\end{array}$ & $\begin{array}{l}141.52(14), \\
83.78(12), \\
82.72(12), \\
128.86(14)\end{array}$ \\
\hline N-Be-N & $117.35(12)^{\circ}$ & - & - \\
\hline $\mathrm{N}-\mathrm{Be}-\mathrm{C}_{\mathrm{bb}}$ & - & $\begin{array}{l}91.9(2), 91.2(2), \\
91.1(2), 90.9(2)\end{array}$ & $\begin{array}{l}89.69(15), \\
89.73(15)\end{array}$ \\
\hline N-P-C $\mathrm{Cb}_{\mathrm{bb}}$ & $\begin{array}{l}109.26(6), \\
110.63(7)\end{array}$ & $\begin{array}{l}\text { 98.15(13), 96.80(12), } \\
97.68(13), 96.65(12)\end{array}$ & $\begin{array}{l}94.72(9), \\
93.84(9)\end{array}$ \\
\hline $\mathrm{P}-\mathrm{N}-\mathrm{Be}$ & $\begin{array}{l}124.16(10), \\
124.52(9)^{\circ}\end{array}$ & $\begin{array}{l}\text { 88.22(17), 89.77(17), } \\
88.97(17), 90.06(17)\end{array}$ & $\begin{array}{l}91.43(12), \\
92.10(12)^{\circ}\end{array}$ \\
\hline $\begin{array}{l}\mathrm{Be}-\mathrm{C}_{b b-} \\
\mathrm{Be}\end{array}$ & - & $94.7(2), 88.9(2)$ & $91.11(14)$ \\
\hline
\end{tabular}

${ }^{\text {[a] }} \mathrm{C}_{\mathrm{bb}}=\mathrm{C}_{\text {backbone. }}$

Despite its electron deficiency, 1 failed to react with strong Lewis bases such as dmap, pyridine, acetonitrile with formation of the corresponding base-coordinated complexes as was found for the analogous lithium complex, ${ }^{[28 \mathrm{e}]}$, most likely resulting from the effective shielding of the electron-deficient Be atom by the sterically demanding Dipp substituents.

We then became interested in twofold deprotonation reactions of bis(diphenylphosphinimino)methanes $\mathrm{H}_{2} \mathrm{C}\left(\mathrm{PPh}_{2} \mathrm{NR}\right)_{2}$ 
in order to investigate the possible formation of dianionic bis(diphenyliminophosphorano)methanediides of the general type $\left[\mathrm{C}\left(\mathrm{PPh}_{2} \mathrm{NR}\right)_{2}\right]^{2-}$, which have been shown in the last decade to be suitable ligands for the stabilization of metal carbene complexes. $^{[21]}$ Mononuclear carbene complexes containing a formal $\mathrm{M}=\mathrm{C}$ double bond have been realized with several metals including group 2 metals, ${ }^{[22]}$ group 3 metals, ${ }^{[23]}$ group 4 metals, ${ }^{[24]}$ group 14 metals, ${ }^{[25]}$ as well as $\mathrm{Bi}^{[26]}$ and $\mathrm{U}$ and Ce. ${ }^{[27]}$ In addition, a few dinuclear metal complexes of the general type $\left[\mathrm{C}\left(\mathrm{PPh}_{2} \mathrm{NR}\right)_{2}\right](\mathrm{MR})_{2}$, in which two metal atoms are bonded to one bis(diphenyliminophosphorano)methanediide ligand, containing alkali metals, aluminum, zinc and lanthanum have been structurally characterized, ${ }^{[28-31]}$ while to the best of our knowledge, analogous dinuclear group 2 metal carbene complexes are unknown, to date. Only dimeric dicalcium and dibarium dicarbene complexes have been reported by Harder et al., respectively. ${ }^{[23]}$

We therefore investigated the equimolar reaction of $\mathrm{H}_{2} \mathrm{C}\left(\mathrm{PPh}_{2} \mathrm{~N}-2 \text {,6- } i \text { - } \mathrm{Pr}_{2} \mathrm{C}_{6} \mathrm{H}_{3}\right)_{2}$ with $\mathrm{BeEt}_{2}$ at higher temperatures, but we could not observe the formation of a beryllium carbene complex. We then turned our attention to reactions of $\mathrm{H}_{2} \mathrm{C}\left[\mathrm{PPh}_{2} \mathrm{NR}\right]_{2} \quad\left(\mathrm{R}=\mathrm{SiMe}_{3}, \mathrm{Ph}, 2,6-i-\mathrm{Pr}_{2} \mathrm{C}_{6} \mathrm{H}_{3}\right)$ with two equivalents of $\mathrm{BeEt}_{2}$. While the reaction of $\mathrm{H}_{2} \mathrm{C}\left(\mathrm{PPh}_{2} \mathrm{~N}-2,6-i-\right.$ $\left.\mathrm{Pr}_{2} \mathrm{C}_{6} \mathrm{H}_{3}\right)_{2}$ containing the sterically most demanding DIPP substituent with even three equivalents of $\mathrm{BeEt}_{2}$ only resulted in the formation of $\left[\mathrm{CH}\left(\mathrm{PPh}_{2} \mathrm{~N}-2,6-i-\mathrm{Pr}_{2} \mathrm{C}_{6} \mathrm{H}_{3}\right)_{2}\right] \mathrm{BeEt} \mathbf{1}$, the reactions of $\mathrm{H}_{2} \mathrm{C}\left[\mathrm{PPh}_{2} \mathrm{NR}\right]_{2}\left(\mathrm{R}=\mathrm{SiMe}_{3}, \mathrm{Ph}\right)$ with two equivalents of $\mathrm{BeEt}_{2}$ gave the corresponding binuclear bis(diphenylphosphinimino)methanediide beryllium complexes $\left[\mathrm{C}\left(\mathrm{PPh}_{2} \mathrm{NR}\right)_{2}\right](\mathrm{BeEt})_{2}\left(\mathrm{R}=\mathrm{SiMe}_{3} 2\right.$, $\left.\mathrm{Ph} \mathrm{3}\right)$, respectively (scheme 2). In contrast to the monometallated derivatives as described before, $\mathbf{2}$ and $\mathbf{3}$ are stable in solution at ambient temperature.
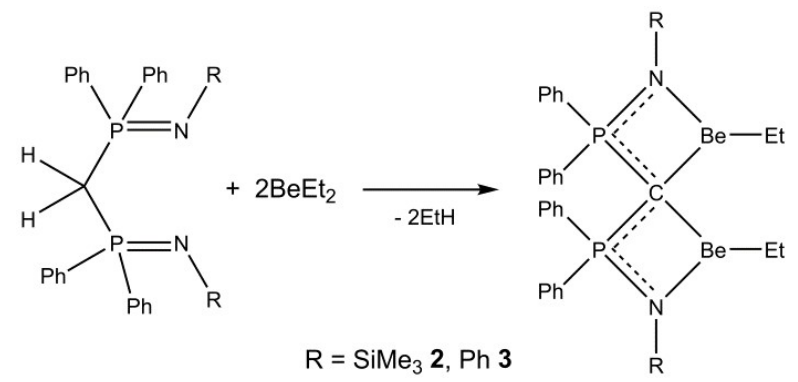

Scheme 2. Synthesis of 2 and 3.

Only a single resonance was observed for the N-substituents $\left(\mathrm{SiMe}_{3}, \mathrm{Ph}\right)$ in $\mathbf{2}$ and $\mathbf{3}$. The ${ }^{13} \mathrm{C}-\left\{{ }^{1} \mathrm{H}\right\}$ NMR spectra of $\mathbf{2}$ and $\mathbf{3}$ don't show any resonance of the quaternary P-C-P carbon atom even after long acquisition times. Comparable findings have been previously reported for the corresponding aluminum complexes and have been explained by the absence of nearby protons and, as a consequence, a bad magnetization transfer, as well as by broadening of the resonance due to coupling to two $\mathrm{Al}(\mathrm{I}=5 / 2)$ nuclei. ${ }^{[28 \mathrm{a}, \mathrm{c}]}$ Coupling of the methine carbon to two Be nuclei $(I=3 / 2)$ obviously has the same effect. In addition, the corresponding Li complexes also did not show the ${ }^{13} \mathrm{C}$ resonance of the quaternary P-C-P carbon atom as a result from from the same quadrupolar effect. These findings clearly underline the close relationship of $\mathrm{Li}$ and $\mathrm{Be}$ (Schrägbeziehung).<smiles></smiles>

A

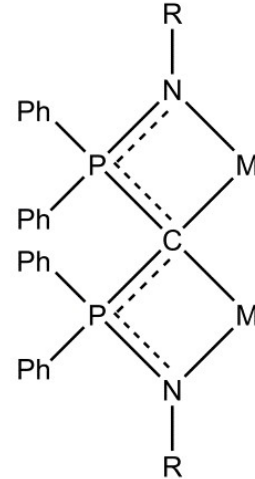

B
Scheme 3. Binding modes observed for the dianionic bis(diphenyliminophosphorano)methanediide ligand.

Bis(diphenyliminophosphorano)methanediides have been shown in the past to either adopt the so-called U-form (A), typically observed with lithium as well as in case of zinc, ${ }^{[28,30]}$ or the $\mathrm{W}$-form (B) as was reported for the aluminum and the lanthanum complexes. ${ }^{[29,31]}$ Both isomeric forms are shown in scheme 3 . We therefore became interested in the solid state structures of $\mathbf{2}$ and $\mathbf{3}$.

Crystals of $\mathbf{2}$ and $\mathbf{3}$ suitable for single crystal X-ray diffraction studies were obtained upon slow re-crystallization from solutions of $\mathbf{2}$ and $\mathbf{3}$ in toluene at ambient temperature. $\mathbf{2}$ crystallizes in the triclinic space group $P-1$ with two independent molecules in the asymmetric unit, while $\mathbf{3}$ crystallizes in the orthorhombic space group $\mathrm{Pbca}$ with one independent molecule in the asymmetric unit. Figure 2 and 3 show the solid state structures of $\mathbf{2}$ and $\mathbf{3}$.

The backbone carbon atoms $\left(\mathrm{C}_{\mathrm{bb}}\right)$ of the starting bis(diphenylphosphinimino)methane ligands are deprotonated twice, resulting in the formation of methanediide fragments which adopt the $\mathrm{W}$-isomeric form in the solid state of both 2 and 3 . The Be cations are coordinated by the methanediide ligand in $\mathrm{C}_{\mathrm{bb}} / \mathrm{N}$-chelating mode, resulting in two spirocyclic four-membered $\mathrm{BeNPC}_{\mathrm{bb}}$ rings (rms deviation from the best plane less than $0.07 \AA$ in all cases). The interplanar angles of $66.3(2)^{\circ}$ and $60.2(2)^{\circ}(2)$ and $59.07(8)^{\circ}(3)$ and their tilt $\left(\mathrm{N} \cdots \mathrm{C}_{\mathrm{bb}} \cdots \mathrm{N}: 153.1(2)^{\circ}\right.$ and $150.1(2)^{\circ}(2) ; 153.5(1)^{\circ}$ (3) $)$ result in a strong distortion of the tetrahedral environment of the methanediide carbon atoms $\mathrm{C}_{\mathrm{bb}}$ (table 1). The Be- $\mathrm{C}_{\mathrm{et}}$ bonds (1.724(5) $\AA 2,1.725 \AA 3$ ) are significantly shorter than the Be$\mathrm{C}_{\mathrm{bb}}$ bond lengths (1.827(5), 1.828(4), 1.817(5), 1.842(5) $\AA 2$, 1.841(3) 1.827(3) A 3), but comparable to those observed in $\mathbf{1}$ $(1.753(2) \AA)$. The short $\mathrm{P}-\mathrm{C}_{\mathrm{bb}}(1.807(3) \AA 2,1.715 \AA 3$ ) and $\mathrm{P}-$ $\mathrm{N}$ bond lengths $(1.620(2) \AA 2,1.638 \AA \mathrm{3})$ are also comparable to those in $\mathbf{1}$ and indicate delocalised $\pi$-electron systems with pronounced double bonding character throughout the whole back-bone of the ligands as was previously observed in bis(diphenyliminophosphorano)methanediide complexes. ${ }^{[28-30]}$ The $\mathrm{sp}^{2}$ hybridisations at the $\mathrm{N}$ atoms, which is necessary for the $\pi$-bonding, is confirmed by the trigonal-planar coordination sphere of the $\mathrm{N}$ atoms (all sums of the bond angles larger than $358^{\circ}$ ). The exocyclic $\mathrm{P}-\mathrm{C}_{\mathrm{bb}}-\mathrm{P}$ bond angles 
$\left(134.29(16) 2,128.87(11)^{\circ} \mathbf{3}\right)$, which are significantly larger than the exocyclic Be1-C1-Be2 bond angles (94.7(2) ${ }^{\circ} \mathbf{2}$, 91.11(14) ${ }^{\circ} 3$ ), are comparable to the endocyclic $\mathrm{P}-\mathrm{C}_{\mathrm{bb}}-\mathrm{P}$ bond

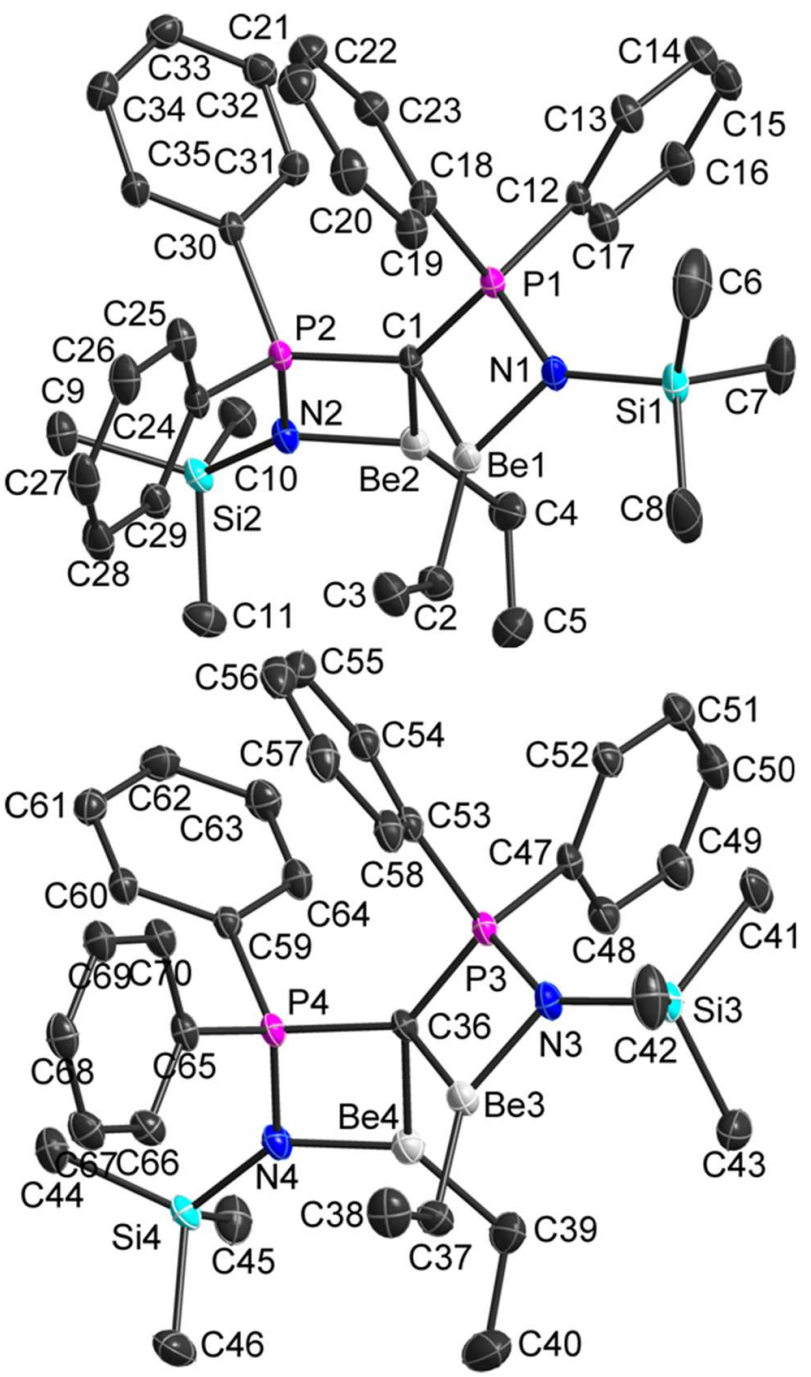

Figure 2. Solid state structure of $2 ; \mathbf{H}$ atoms are omitted for clarity. Thermal ellipsoids are shown at $50 \%$ probability levels. The orientation of the molecules does not resemble their orientation in the asymmetric unit.

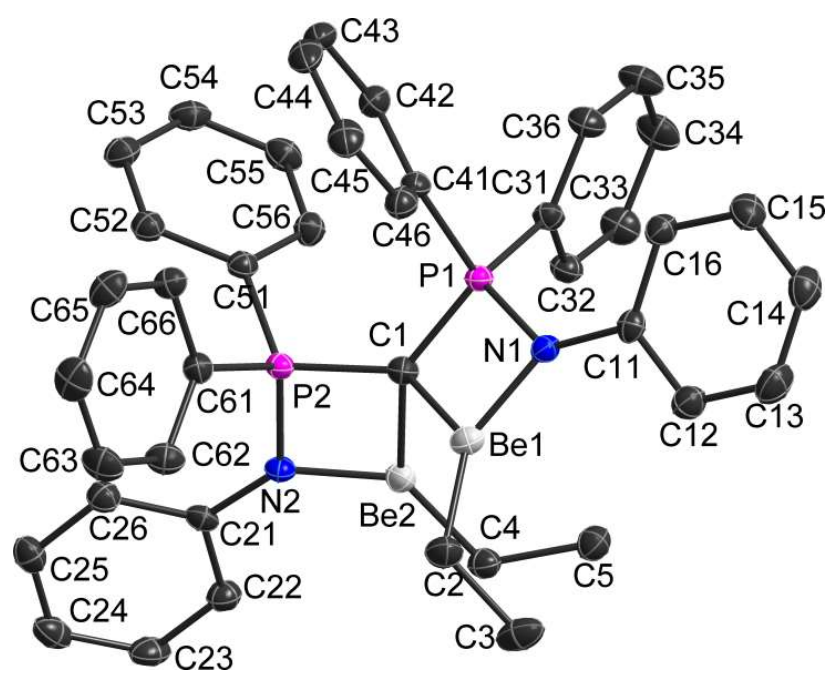

Figure 3. Solid state structure of $3 ; \mathrm{H}$ atoms are omitted for clarity. Thermal ellipsoids are shown at $50 \%$ probability levels.

angle in $1\left(129.53(8)^{\circ}\right)$, while the endocyclic $\mathrm{Cbb}-\mathrm{P}-\mathrm{N}$ bond angles (av. values $97.48(13) \mathbf{2}, 94.28(9)^{\circ}$ 3) are significantly smaller compared to those of $\mathbf{1}\left(109.95(7)^{\circ}\right)$, most likely resulting from the smaller ring size. Short Be-Be distances of 2.687(5) $\AA$ (2) and $2.619(4) \AA(3)$ are observed, which clearly exceed the sum of the covalent radii $(2.04 \AA),{ }^{[32]}$ but are well below the sum of the vander Waals radii $(3.06 \AA) .{ }^{[33]}$

\section{CONCLUSION}

Bis(diphenylphosphinimino)methanide beryllium complexes were formed in ethane elimination reactions between equimolar amounts of $\mathrm{H}_{2} \mathrm{C}\left(\mathrm{PPh}_{2} \mathrm{NR}\right)_{2}$ and $\mathrm{BeEt}_{2}$, but only $\left[\mathrm{CH}\left(\mathrm{PPh}_{2} \mathrm{~N}-2,6-i-\mathrm{Pr}_{2} \mathrm{C}_{6} \mathrm{H}_{3}\right)_{2}\right] \mathrm{BeEt} 1$ was found to be stable at ambient temperature. In addition, reactions of $\mathrm{H}_{2} \mathrm{C}\left(\mathrm{PPh}_{2} \mathrm{NR}\right)_{2}$ with two equivalents of $\mathrm{BeEt}_{2}$ yielded the first bis(diphenylphosphinimino)methanediide complexes $\left[\mathrm{C}\left(\mathrm{PPh}_{2} \mathrm{NSiMe}_{3}\right)_{2}\right](\mathrm{BeEt})_{2} \quad \mathbf{2}$ and $\left[\mathrm{C}\left(\mathrm{PPh}_{2} \mathrm{NPh}\right)_{2}\right](\mathrm{BeEt})_{2} \quad \mathbf{3}$, while the reaction of $\mathrm{H}_{2} \mathrm{C}\left(\mathrm{PPh}_{2} \mathrm{~N}-2,6-i-\mathrm{Pr}_{2} \mathrm{C}_{6} \mathrm{H}_{3}\right)_{2}$ containing the sterically most demanding $\mathrm{N}$-substituent with even three equivalents of $\mathrm{BeEt}_{2}$ only gave $\mathbf{1}$. These studies clearly prove the strong deprotonating properties of $\mathrm{BeEt}_{2}$, which is comparable to those of lithium alkyls and aluminum alkyls. In remarkable contrast to the results from twofold deprotonation reactions of $\mathrm{H}_{2} \mathrm{C}\left(\mathrm{PPh}_{2} \mathrm{NR}\right)_{2}$ with calcium and barium complexes, which yielded dimeric dimetal dicarbene complexes, the reactions with $\mathrm{BeEt}_{2}$ also occurred with twofold deprotonation but formation of dinuclear complexes $\mathbf{2}$ and $\mathbf{3}$, which are without precedence in group 2 metal chemistry.

\section{EXPERIMENTAL SECTION}

General Procedures. Caution! Beryllium and its compounds are regarded as highly toxicand carcinogenic and have allergic potential when inhaled, with risk of causing chronic beryllium disease (CBD).$^{[34]}$ They should therefore be handled with appropriate safety precautions. All manipulations were performed in a Glovebox (MBraun) under an Ar atmosphere or with standard Schlenk techniques. Solvents were carefully dried over $\mathrm{Na} / \mathrm{K}$ and degassed prior to use. Bis(iminophosphorano)methanes ${ }^{[35]}$ and $\mathrm{BeEt}_{2}{ }^{[36]}$ were prepared according to literature procedures. NMR spectra were recorded on a Bruker Avance 300 spectrometer at $25^{\circ} \mathrm{C}$ at $300 \mathrm{MHz}\left({ }^{1} \mathrm{H}\right), 42 \mathrm{MHz}$ $\left({ }^{9} \mathrm{Be}\right), 75 \mathrm{MHz}\left({ }^{13} \mathrm{C}\right)$ and $121 \mathrm{MHz}\left({ }^{31} \mathrm{P}\right)$, respectively, and referenced to internal $\mathrm{C}_{6} \mathrm{D}_{5} \mathrm{H}\left({ }^{1} \mathrm{H}: \delta=7.154 ;{ }^{13} \mathrm{C}: \delta=128.0\right)$. IR spectra were 
recorded on a Bruker ALPHA-T FT-IR spectrometer equipped with a single reflection ATR sampling module. Melting points were measured in sealed capillaries and were not corrected. Elemental analyses were not determined due to the expected toxicity of $\mathbf{1}$ - $\mathbf{3}$. Their purity was checked by NMR spectroscopy.

$\left[\mathbf{C H}\left(\mathbf{P P h}_{2} \mathbf{N}-\mathbf{2}, \mathbf{6}-\boldsymbol{i}-\mathbf{P r}_{2} \mathbf{C}_{6} \mathbf{H}_{3}\right)_{2}\right] \mathbf{B e E t} \quad \mathbf{1} .0 .20 \mathrm{~g} \quad(0.35 \mathrm{mmol})$ $\mathrm{H}_{2} \mathrm{C}\left(\mathrm{PPh}_{2} \mathrm{~N}-2,6-i-\mathrm{Pr}_{2} \mathrm{C}_{6} \mathrm{H}_{3}\right)_{2}$ was dissolved in $15 \mathrm{~mL}$ of toluene at -78 ${ }^{\circ} \mathrm{C}$ and $0.024 \mathrm{~g}$ (0.35 mmol) $\mathrm{BeEt}_{2}$ was added via syringe to the pale orange solution. The solution was allowed to warm to ambient temperature over night. The solvent was removed in vacuum and the resulting crude product was washed with cold pentane. Recrystallization of the remaining solid in a minimum amount of toluene at $20^{\circ} \mathrm{C}$ yielded colorless crystals within $24 \mathrm{~h}$.

Yield: $0.25 \mathrm{~g}(93 \%)$. Mp.: $>220{ }^{\circ} \mathrm{C}$ (dec.). ${ }^{1} \mathrm{H}$ NMR $(300 \mathrm{MHz}$, $\mathrm{C}_{6} \mathrm{D}_{6}, 25{ }^{\circ} \mathrm{C}$ ): $\delta=-0.24$ (quart, $2 \mathrm{H},{ }^{3} J_{\mathrm{HH}}=8.3 \mathrm{~Hz}, \mathrm{BeCH}_{2} \mathrm{CH}_{3}$ ), 0.48 $\left(\mathrm{d}, 12 \mathrm{H},{ }^{3} J_{\mathrm{HH}}=6.9 \mathrm{~Hz}, \mathrm{CH}\left(\mathrm{CH}_{3}\right)_{2}\right), 0.50\left(\mathrm{t}, 3 \mathrm{H},{ }^{3} J_{\mathrm{HH}}=8.2 \mathrm{~Hz}\right.$, $\left.\mathrm{BeCH}_{2} \mathrm{CH}_{3}\right), 1.02(\mathrm{~s}, 1 \mathrm{H}, \mathrm{PCHP}), 1.48\left(\mathrm{~d}, 12 \mathrm{H},{ }^{3} J_{\mathrm{HH}}=6.9 \mathrm{~Hz}\right.$, $\left.\mathrm{H}\left(\mathrm{CH}_{3}\right)_{2}\right), 3.78$ (sept, $\left.4 \mathrm{H},{ }^{3} \mathrm{~J}_{\mathrm{HH}}=6.8, \mathrm{CH}\left(\mathrm{CH}_{3}\right)_{2}\right), 6.89-7.20(\mathrm{~m}, 18 \mathrm{H}$, $\left.\mathrm{Ph}_{2} \mathrm{P}, 2,6-i-\mathrm{Pr}_{2}-\mathrm{C}_{6} \mathrm{H}_{3}\right), 7.53-7.59\left(\mathrm{~m}, 8 \mathrm{H}, \mathrm{o}-\mathrm{Ph}_{2} \mathrm{P}\right) .{ }^{13} \mathrm{C}$ NMR $(75 \mathrm{MHz}$, $\left.\mathrm{C}_{6} \mathrm{D}_{6}, 25{ }^{\circ} \mathrm{C}\right): 11.3\left(\mathrm{BeCH}_{2} \mathrm{CH}_{3}\right), 12.2\left(\mathrm{BeCH}_{2} \mathrm{CH}_{3}\right), 23.3$ (PCHP), $25.4\left(\mathrm{CH}\left(\mathrm{CH}_{3}\right)_{2}\right), 29.3\left(\mathrm{CH}\left(\mathrm{CH}_{3}\right)_{2}\right), 124.3\left(p-P h_{P}\right), 125.5\left(p-P h_{N}\right)$, $127.3\left(m-P h_{P}\right), 128.9\left(m-P h_{N}\right), 130.6\left(o-P h_{N}\right), 133.2\left(\mathrm{t},{ }^{2} J_{\mathrm{CP}}=4.8 \mathrm{~Hz}\right.$, $\left.o-P h_{P}\right), 142.2\left(\mathrm{t},{ }^{1} J_{\mathrm{CP}}=4.5 \mathrm{~Hz}, i-P h_{P}\right), 147.3\left(\mathrm{t},{ }^{2} J_{\mathrm{CP}}=2.6 \mathrm{~Hz}, i-P h_{N}\right)$. ${ }^{9} \mathrm{Be}$ NMR $\left(300 \mathrm{MHz}, \mathrm{C}_{6} \mathrm{D}_{6}, 25{ }^{\circ} \mathrm{C}\right) \delta=15.62 .{ }^{31} \mathrm{P}$ NMR $(300 \mathrm{MHz}$, $\left.\mathrm{C}_{6} \mathrm{D}_{6}, 25{ }^{\circ} \mathrm{C}\right) \delta=29.95$. ATR-IR: $\widetilde{v}=3052,2961,2946,2924,2865$, 2846, 1588, 1576, 1456, 1382, 1361, 1316, 1238, 1177, 1097, 1042, 1027, 1008, 989, 949, 925, 892, 822, 803, 725, 691, 676, 607, 546, $501,485,450,390 \mathrm{~cm}^{-1}$

General synthesis of $\left[\mathbf{C}\left(\mathbf{P P h}_{2} \mathbf{N R}\right)_{2}\right] \mathrm{Be}_{2} \mathbf{E t}_{2} . \mathrm{H}_{2} \mathrm{C}\left(\mathrm{PPh}_{2} \mathrm{NR}\right)_{2}(\mathrm{R}=$ $\mathrm{SiMe}_{3}, 0.20 \mathrm{~g}, 0.36 \mathrm{mmol}$; Ph, $\left.0.20 \mathrm{~g}, 0.48 \mathrm{mmol}\right)$ was dissolved in 15 $\mathrm{mL}$ toluene at $-78{ }^{\circ} \mathrm{C}$ and a twofold amount of $\mathrm{BeEt}_{2}(0.048 \mathrm{~g}, 0.72$ mmol; $0.064 \mathrm{~g}, 0.96 \mathrm{mmol})$ was added via syringe to the solution. The solution was allowed to warm to ambient temperature within $12 \mathrm{~h}$. The solvent was removed in vacuum and the crude product was washed with cold pentane. Re-crystallization of the remaining solid in a minimum amount of toluene at $20{ }^{\circ} \mathrm{C}$ yielded colorless crystals within $24 \mathrm{~h}$.

[C(PPh $\left.\left.\mathbf{N S i M e}_{3}\right)_{2}\right](\mathbf{B e E t})_{2} 2$ 2. Yield: $0.21 \mathrm{~g}(90 \%) . \mathrm{Mp} .:>220{ }^{\circ} \mathrm{C}$ (dec.). ${ }^{1} \mathrm{H}$ NMR $\left(300 \mathrm{MHz}, \mathrm{C}_{6} \mathrm{D}_{6}, 25{ }^{\circ} \mathrm{C}\right): \delta=0.10$ (s, 18H, $\left.\mathrm{SiMe}_{3}\right)$, $0.55-0.74\left(2\right.$ quart, $\left.4 \mathrm{H},{ }^{3} J_{\mathrm{HH}}=8.0 \mathrm{~Hz}, \mathrm{BeCH}_{2} \mathrm{CH}_{3}\right), 1.67\left(\mathrm{t}, 6 \mathrm{H},{ }^{3} J_{\mathrm{HH}}=\right.$ $\left.8.2 \mathrm{~Hz}, \mathrm{BeCH}_{2} \mathrm{CH}_{3}\right)$, 6.73-6.80 (m, 4H, Ph), 6.87-6.94 (m, 2H, Ph), 7.03-7.09 (m, 6H, Ph), 7.18-7.26 (m, 4H, Ph), 7.55-7.62 (m, 4H, o$\left.\mathrm{Ph}_{2} \mathrm{P}\right) .{ }^{13} \mathrm{C}$ NMR $\left(75 \mathrm{MHz}, \mathrm{C}_{6} \mathrm{D}_{6}, \quad 25{ }^{\circ} \mathrm{C}\right): 3.0 \quad\left(\mathrm{SiMe}_{3}\right), 4.2$ $\left(\mathrm{BeCH}_{2} \mathrm{CH}_{3}\right), 12.2\left(\mathrm{BeCH}_{2} \mathrm{CH}_{3}\right), 128.4-128.7(\mathrm{~m}, m-P h P), 131.5(m-$ $\left.P h_{N}\right), 131.7\left(o-P h_{P}\right), 132.3-132.5\left(\mathrm{dt},{ }^{3} J_{\mathrm{CP}}=5.9, o-P h_{N}\right), 134.7\left(i-P h_{P}\right)$, $135.9\left(i-P h_{N}\right) .{ }^{9} \mathrm{Be}$ NMR $\left(300 \mathrm{MHz}, \mathrm{C}_{6} \mathrm{D}_{6}, 25{ }^{\circ} \mathrm{C}\right) \delta=0.93 .{ }^{31} \mathrm{P}$ NMR $\left(300 \mathrm{MHz}, \mathrm{C}_{6} \mathrm{D}_{6}, 25^{\circ} \mathrm{C}\right) \delta=28.06$. ATR-IR: $\widetilde{v}=3058,2955,2932$, 2894, 2854, 2838, 1590, 1482, 1454, 1435, 1408, 1309, 1245, 1227, $1191,1133,1111,1083,1026,990,955,916,833,791,770,744$, $721,668,621,595,564,529,507,457,427,384 \mathrm{~cm}^{-1}$

[C(PPh $\left.\mathbf{P P h}_{2} \mathbf{N P}\right)_{(\mathbf{B e E t})_{2}}$ 3. Yield: $0.28 \mathrm{~g}(87 \%) . \mathrm{Mp} .:>220{ }^{\circ} \mathrm{C}$ (dec.). ${ }^{1} \mathrm{H}$ NMR $\left(300 \mathrm{MHz}, \mathrm{C}_{6} \mathrm{D}_{6}, 25{ }^{\circ} \mathrm{C}\right): \delta=0.81-0.84$ (2 quart, $4 \mathrm{H}$, $\left.{ }^{3} J_{\mathrm{HH}}=8.0 \mathrm{~Hz}, \mathrm{BeCH}_{2} \mathrm{CH}_{3}\right), 1.70\left(\mathrm{t}, 6 \mathrm{H},{ }^{3} \mathrm{~J}_{\mathrm{HH}}=8.2 \mathrm{~Hz}, \mathrm{BeCH}_{2} \mathrm{CH}_{3}\right)$, 6.65-6.74 (m, 6H,Ph), 6.86-7.00 (m, 12H,Ph), $7.12(\mathrm{~m}, 4 \mathrm{H}, P h)$, 7.56-7.64 (m, 4H, o-Ph 2 P). ${ }^{13} \mathrm{C}$ NMR $\left(75 \mathrm{MHz}, \mathrm{C}_{6} \mathrm{D}_{6}, 25{ }^{\circ} \mathrm{C}\right): 3.7$ $\left(\mathrm{BeCH}_{2} \mathrm{CH}_{3}\right), 12.0\left(\mathrm{BeCH}_{2} \mathrm{CH}_{3}\right), 121.8\left(\mathrm{t},{ }^{4} J_{\mathrm{CP}}=7.0, p-P h P\right), 128.7$ $\left(m-P h_{P}\right), 128.8-129.0\left(\mathrm{dt},{ }^{4} J_{\mathrm{CP}}=5.6 \mathrm{~Hz}, m-P h_{N}\right), 129.7\left(o-P h_{P}\right), 132.0$ $\left(o-P h_{N}\right), 132.8-132.9\left(\mathrm{dt},{ }^{1} J_{\mathrm{CP}}=5.4 \mathrm{~Hz}, i-P h_{P}\right), 146.3\left(i-P h_{N}\right) .{ }^{9} \mathrm{Be}$ NMR $\left(300 \mathrm{MHz}, \mathrm{C}_{6} \mathrm{D}_{6}, 25{ }^{\circ} \mathrm{C}\right) \delta=19.23 .{ }^{31} \mathrm{P} \mathrm{NMR}\left(300 \mathrm{MHz}, \mathrm{C}_{6} \mathrm{D}_{6}\right.$, $\left.25^{\circ} \mathrm{C}\right) \delta=29.32$. ATR-IR: $\widetilde{v}=3054,3034,2924,2887,2850,2775$, $2717,1592,1572,1486,1434,1310,1274,1141,175,1015,980$, $809,788,755,740,719,690,604,561,522,504,484,448,381 \mathrm{~cm}^{-1}$.

Single crystal X-ray analyses. Crystallographic data of $\mathbf{1}$ to $\mathbf{3}$, which were collected on a Bruker AXS APEX 2 diffractometer (MoK $\alpha$ radiation, $\lambda=0.71073 \AA$ ), are summarized in Table S1 (Supporting Information), while central bond lengths and angles are summarized in table 1. Figures 1 - 3 show diagrams of the solid-state structures of 1 - 3. Data were collected at 101(1) K. The structures were solved by Direct Methods (SHELXS-97) and refined anisotropically by full-matrix least-squares on $\mathrm{F}^{2}$ (SHELXL2013). ${ }^{[37]}$ Absorp- tion corrections were performed semi-empirically from equivalent reflections on basis of multi-scans (Bruker AXS APEX2, TWINABS). 1 was a non-merohedrally twinned crystal and the structure model was refined against de-twinned HKLF4 data. 2 was pseudo-merohedrally twinned by a 2-fold ratational axis parallel to $b$.

The crystallographic data of $\mathbf{1}$ to $\mathbf{3}$ (excluding structure factors) have been deposited with the Cambridge Crystallographic Data Centre as supplementary publication nos. CCDC-1478801 (1), CCDC1478803(2), and CCDC-1478802(3). Copies of the data can be obtained free of charge on application to CCDC, 12 Union Road, Cambridge, CB21EZ (fax: (+44) 1223/336033; e-mail: deposit@ccdc.cam-ak.uk).

\section{ASSOCIATED CONTENT}

\section{Supporting Information}

Electronic Supplementary Information (ESI) available: A CIF file giving X-ray crystallographic data of $\mathbf{1}$ to $\mathbf{3}$. In addition, ${ }^{1} \mathrm{H},{ }^{9} \mathrm{Be}$, ${ }^{13} \mathrm{C},{ }^{31} \mathrm{P}$ NMR and IR spectra as well as the crystallographic details of $\mathbf{1}$ to $\mathbf{3}$ are given. This material is available free of charge via the Internet at http://pubs.acs.org.

\section{AUTHOR INFORMATION}

\section{Corresponding Author}

* To whom correspondence should be addressed. Prof. Dr. Stephan Schulz, Institute of Inorganic Chemistry, University of Duisburg-Essen, 45117 Essen, Germany; Phone: +49 0201-1834635; Fax: + 49 0201-1833830; e-mail: stephan.schulz@uni-due.de.

\section{Author Contributions}

The manuscript was written through contributions of all authors. All authors have given approval to the final version of the manuscript.

Notes

The authors declare no competing financial interest.

\section{ACKNOWLEDGMENT}

S. Schulz thanks the University of Duisburg-Essen for financial support and Materion company for providing beryllium metal.

\section{REFERENCES}

[1] Bruce, R. M.; Odin, M. Concise International Chemical Assessment Document 32: Beryllium and Beryllium Compounds, World Health Organization, Geneva (2001)

[2] For recent review articles see: a) Iversen, K. J.; Couchman, S. A.; Wilson, D. J. D.; Dutton, J. L. Coord. Chem. Rev. 2015, 297-298, 40-48; b) Bellemin-Laponnaz, S.; Dagorne, S. Chem. Rev. 2014, 114, 8747-8774; c) M. S. Hill Inorg. Chem. 2013, 109, 18-27.

[3] Fischer, E. O.; Hofmann, H. P. Chem. Ber. 1959, 92, 482-486.

[4] a) Nugent, K. W.; Beattie, J. K.; Hambley, T. W.; Snow M. R. Aust. J. Chem. 1984, 37, 1601-1606; b) Wong, C. H.; Lee, T. Y.; Chao, K. J.; Lee S. Acta Crystallogr. Sect. B 1972, 28, 1662-1665; c) Wong, C. H.; Lee, T. Y.; Lee, T. J.; Chang, T. W.; Liu C. S. Inorg Nucl. Chem. Lett. 1973, 9, 667-673; d) Conejo, M. M.; Fernández, R.; Gutiérrez-Puebla, E.; Monge, Á.; Carmona, E.; Angew. Chem. 2000, 112, 2025-2027; Angew. Chem. Int. Ed. 2000, 39, 1949-1951; e) Conejo, M. M.; Fernández, R.; del Río, D.; Carmona, E.; Monge, Á.; Ruiz, C. Chem. Commun. 2002, 23, 2916-2917; f) del Mar Conejo, M.; Fernández, R.; del Río, D.; Carmona, E.; Monge, Á.; Ruiz, C.; Márquez, A. M.; Sanz, J. F. Chem. - Eur. J. 2003, 9, 4452-4461; g) Hung, I.; Macdonald, C. L. B.; Schurko, R. W. Chem. - Eur. J. 2004, 10, 5923-5935; h) Fernández, R.; Carmona, E. Eur. J. Inorg. Chem. 2005, 3197-3206; i) D. Himmel, H. Scherer, D. Kratzert, I. Krossing, Z. Anorg. Allg. Chem. 2015, 641, 655-659. 
[5] a) Wong, C.; Wang, S. Inorg. Nucl. Chem. Lett. 1975, 11, 677678; b) Nugent, K. W.; Beattie, J. K.; Field L. D. J. Phys. Chem. 1989, 93, 5371-5377.

[6] Almenningen, A.; Haaland, A.; Lusztyk, J. J. Organomet. Chem. 1979, 170, 271-284.

[7] a) Marinyk, D. S. J. Am. Chem. Soc. 1977, 99, 1436-1441; b) Chiu, N. S.; Schäfer, L. J. Am. Chem. Soc. 1978, 100, 2604-2607; c) Jemmis, E. D.; Alexandratos, S.; Schleyer, P. R.; Streitwieser, A.; Schaefer, H. F. J. Am. Chem. Soc. 1978, 100, 5695-5700; d) Gleiter, R.; Böhm, M.; Haaland, A.; Johansen, R.; Lusztyk, J. J. Organomet. Chem. 1979, 170, 285-292; e) Margl, P.; Schwarz, K.; Blöchl, P. E. J. Chem. Phys. 1995, 103, 683-690.

[8] K. Ruhlandt-Senge, R. A. Bartlett, M. M. Olmstead, P. P. Power Inorg. Chem. 1993, 32, 1724-1728; b) M. Niemeyer, P. P. Power Inorg. Chem. 1997, 36, 4688-4696.

[9] a) Herrmann, W. A.; Runte, O.; Artus, G. J. Organomet. Chem. 1995, 501, C1-C4; b) Gottfriedsen, J.; Blaurock, S. Organometallics 2006, 25, 3784-3786; c) Gilliard, R. J.; Abraham, M. Y.; Wang, Y.; Wei, P.; Xie, Y.; Quillian, B.; Schaefer III, H. F.; Schleyer, P. v. R.; Robinson, G. H. J. Am. Chem. Soc. 2012, 134, 9953-9955; d) Arrowsmith, M. Hill, M. S.; Kociok-Köhn, G.; MacDougall, D. J.; Mahon, M. F. Angew. Chem. Int. Ed. 2012, 51, 2098-2100, Angew. Chem. 2012, 124, 2140-2142; e) Iversen, K. J.; Wilson, D. J. D.; Dutton, J. L. Organometallics 2013, 32, 6209-6217; f) Iversen, K. J.; Wilson, D. J. D.; Dutton, J. L. Dalton Trans. 2014, 43, 12820-12823; g) Arrowsmith, M. Hill, M. S.; Kociok-Köhn, G. Organometallics 2015, 34, 653-662; h) Nijesh, K.; De, S.; Parameswaran, P. Dalton Trans. 2016, 45, 7836-7846.

[10] a) Velazquez, A.; Fernández, I.; Frenking, G.; Merino, G. Organometallics 2007, 26, 4731-4736; b) Hatua, K.; Nandi P. K. $J$. Phys. Chem. A 2013 117, 12581-12589; c) Couchman, S. A.; Holzmann, N.; Frenking, G.; Wilson, D. J. D.; Dutton, J. L. Dalton Trans. 2013, 42, 11375-11384; d) Field-Theodore, T. E.; Wilson, D. J. D.; Dutton, J. L. Inorg. Chem. 2015, 54, 8035-8041.

[11] See the following and references cited therein: a) Wang, Y.; Quillian, B.; Wei, P.; Wang, H.; Yang, X.-J.; Xie, Y.; King, R. B.; Schleyer, P. v. R.; Schaefer III, H. F.; Robinson, G. H. J. Am. Chem. Soc. 2005, 127, 11944-11945; b) Green, S. P.; Jones, C.; Stasch, A. Science 2007, 318, 1754-1757; c) Schulz, S.; Schuchmann, D.; Westphal, U.; Bolte, M. Organometallics 2009, 28, 1590-1592; d) Gondzik, S.; Bläser, D.; Wölper, C.; Schulz, S. Chem. Eur. J. 2010, 16, 13599-13602; e) Stasch, A.; Jones, C. Dalton Trans. 2011, 40, 56595672; f) Li, T.; Schulz, S.; Roesky, P. W. Chem. Soc. Rev. 2012, 41, 3759-3771.

[12] a) Niemeyer, M.; Power, P. P. Inorg. Chem. 1997, 36, 46884696; Neumüller, B.; Dehnicke, K. Z. Anorg. Allg. Chem. 2003, 629, 2529-2534.

[13] a) Arrowsmith, M.; Crimmin, M. R.; Hill, M. S.; KociokKöhn, G. Dalton Trans. 2013, 42, 9720-9726; b) Arrowsmith, M.; Hill, M. S.; Kociok-Köhn, G.; MacDougall, D. J.; Mahon, M. F.; Mallow, I. Inorg. Chem. 2012, 51, 13408-13418; c) Bonyhady, S. J.; Jones, C.; Nembenna, S.; Stasch, A.; Edwards, A. J.; McIntyre, G. J. Chem. Eur. J. 2010, 16, 938-955.

[14] Pan, S.; Saha, R.; Chattaraj, P. K. New. J. Chem. 2015, 39, 6778-6786.

[15] Naglav, D.; Tobey, B.; Neumann, A.; Bläser, D.; Wölper, C.; Schulz, S. Organometallics 2015, 34, 3072-3078.

[16] a) Naglav, D.; Bläser, D.; Wölper, C.; Schulz, S. Inorg. Chem. 2014, 53, 1241-1249; b) Naglav, D.; Tobey, B.; Wölper, C.; Bläser, D.; Jansen, G.; Schulz, S. Eur. J. Inorg. Chem. 2015, DOI: $10.1002 /$ ejic. 201501433 .

[17] Naglav, D.; Neumann, A.; Bläser, D.; Wölper, C.; Haack, R.; Jansen, G.; Schulz, S. Chem. Commun. 2015 51, 3889-3891.

[18] A. Kasani, R. McDonald, R. G. Cavell, Organometallics 1999, 18, 3775-3777.

[19] S. Schulz, S. Gondzik, D. Schuchmann, U. Westphal, L. Dobrzycki, R. Boese, S. Harder, Chem. Commun. 2010, 46, 77577759.

[20] 294 hits for six-membered-rings $\mathrm{MN}_{2}\left(\mathrm{PPh}_{2}\right)_{2} \mathrm{C}(\mathrm{M}=$ any metal) are found in the $\mathrm{CCDC}$ database with the following average values: P-N $1.610 \AA$ \& P-C $1.724 \AA$, N-P-C 108.31 ${ }^{\circ}$, P-C-P $132.25^{\circ}$.
[21] For recent review articles see: a) Liddle, S. T.; Mills, D. P.; Wooles, A. J. Chem. Soc. Rev. 2011, 40, 2164-2176; b) Panda, T. K.; Roesky, P. W. Chem. Soc. Rev. 2009, 38, 2782-2804; c) Gessner, V. H.; Becker, J.; Feichtner, K.-S. Eur. J. Inorg. Chem. 2015, 18411859, d) Harder, S. Coord. Chem. Rev. 2011, 255, 1252-1267.

[22] Orzechowski, L.; Jansen, G.; Harder, S. J. Am. Chem. Soc. 2006, 128, 14676-14684; Orzechowski, L.; Harder, S. Organometallics 2007, 26, 2144-2148; Orzechowski, L.; Harder, S. Organometallics 2007, 26, 5501-5506.

[23] a) Mills, D. P.; Soutar, L.; Cooper, O. J.; Lewis, W.; Blake, A. J.; Liddle, S. T. Organometallics 2013, 32, 1251-1264; b) Mills, D. P.; Wooles, A. J.; McMaster, J.; Lewis, W.; Blake, A. J.; Liddle, S. T. Organometallics 2009, 28, 6771-6776; c) Mills, D. P.; Lewis, W.; Blake, A. J.; Liddle, S. T. Organometallics 2013, 32, 1239-1250; d) Liddle, S. T.; McMaster, J.; Green, J. C.; Arnold, P. L. Chem. Commun. 2008, 1747-1749; e) Aparna, K.; Ferguson, M.; Cavell, R. G. $J$. Am. Chem. Soc. 2000, 122, 726-727; f) Gregson, M.; Lu, E. McMaster, J. Lewis, W. Blake, A. J. Liddle, S. T. Angew. Chem. 2013, 125, 13254-13257; Angew. Chem. Int. Ed. 2013, 52, 13016-13019.

[24] a) Cavell, R. G.; Kamalesh Babu, R. P.; Kasani, A.; McDonald, R. J. Am. Chem. Soc. 1999, 121, 5805-5806; b) Kamalesh Babu, R. P.; McDonald, R.; Cavell, R. G. Chem. Commun. 2000, 481-482; Guo, J.-Y.; Chan, Y.-C.; Li, Y.; Ganguly, R.; So, C.-W. Organometallics 2015, 34, 1238-1244.

[25] Leung, W.-P.; Wang, Z.-X.; Li, H.-W.; Mak, T. C. W. Angew. Chem. Int. Ed. 2001, 40, 2501-2503, Angew. Chem. 2001, 113, 25692571.

[26] Sindlinger, C. P.; Stasch, A.; Wesemann, L. Organometallics 2014, 33, 322-328.

[27] a) Mills, D. P.; Cooper, O. J.; Tuna, F.; McInnes, E. J. L.; Davies, E. S.; McMaster, J.; Moro, F.; Lewis, W.; Blake, A. J.; Liddle, S. T. J. Am. Chem. Soc. 2012, 134, 10047-10054; b) Cooper, O. J.; Mills, D. P.; McMaster, J.; Moro, F.; Davies, E. S.; Lewis, W.; Blake, A. J.; Liddle, S. T. Angew. Chem. 2011, 123, 2431-2434; Angew. Chem. Int. Ed. 2011, 50, 2383-2386; c) Mills, D. P.; Moro, F.; McMaster, J.; van Slageren, J.; Lewis, W.; Blake, A. J.; Liddle, S. T. Nat. Chem. 2011, 3, 454-460.

[28] a) Hull, K. L.; Noll, B. C.; Henderson, K. W. Organometallics 2006, 25, 4072-4074; b) Demange, M.; Boubekeur, L.; Auffrant, A.; Mézailles, N.; Ricard, L.; Le Goff, X.; Le Floch, P. New J. Chem. 2006, 30, 1745-1754; c) Sindlinger, C. P.; Stasch, A. Dalton Trans. 2014, 43, 14334-14345; d) Hull, K. L.; Carmichael, I.; Noll, B. C.; Henderson, K. W. Chem. Eur. J. 2008, 14, 3939-3953; e) Cooper, O. J.; Wooles, A. J.; McMaster, J.; Lewis, W.; Blake, A. J.; Liddle, S. T. Angew. Chem. Int. Ed. 2010, 49, 5570-5573, Angew. Chem. 2010, 122, 5702-5705; f) Ong, C. M.; Stephan, D. W. J. Am. Chem. Soc. 1999, 121, 2939-2940; g) Feichtner, K.-S.; Gessner, V. H. Dalton Trans. 2014, 43, 14399-14408.

[29] a) Aparna, K.; McDonald, R.; Ferguson, M.; Cavell, R. G. Organometallics 1999, 18, 4241-4243; b) Cavell, R. G.; Aparna, K.; Kamalesh Babu, R. P.; Wang, Q. J. Mol. Catal. A: Chem. 2002, 189, 137-143; c) Sindlinger, C. P.; Stasch, A. Aust. J. Chem. 2013, 66, 1219-1225.

[30] Bollwein, T.; Westerhausen, M.; Pfitzner, A. Z. Naturforsch. 2003, $58 b, 493-495$.

[31] Wooles, A. J.; Cooper, O. J.; McMaster, J.; Lewis, W.; Blake, A. J.; Liddle, S. T.; Organometallics 2010, 29, 2315-2321.

[32] P. Pyykkö and M. Atsumi, Chem. Eur. J. 2009, 15, 186-197.

[33] M. Mantina, A. C. Chamberlin, R. Valero, C. J. Cramer, and D. G. Truhlar, J. Phys. Chem. A 2009, 113, 5806-5812.

[34] a) Handa, T.; Nagai, S.; Kitaichi, M.; Chin, K.; Ito, Y.; Oga, T.; Takahashi, K.; Watanabe, K.; Mishima, M.; Izumi, T. Sarcoidosis Vasculitis and Diffuse Lung Diseases 2009, 26, 24-31; b) Strupp, C. Ann. Occup. Hyg. 2011, 55, 43-56; c) Strupp, C. Ann. Occup. Hyg. 2011, 55, 30-42; d) Cummings, K. J.; Stefaniak, A. B.; Abbas Virji, M.; Kreiss K., Environmental Health Perspectives 2009, 117, 12501256; e) Bill, J. R.; Mack, D. G.; Falta, M. T.; Maier, L. A.; Sullivan, A. K.; Joslin, F. G.; Martin, A. K.; Freed, B. M.; Kotzin, B. L.; Fontenot, A. P. J. Immunology 2005, 175, 70297037; f) Schmidbaur, H. Coord. Chem. Rev. 2001, 215, 223-242; g) Dehnicke, K.; B. Neumüller, Z. Anorg. Allg. Chem. 2008, 634, 2703-2728. See also the follow- 
ing review article on beryllium chemistry including detailed safety instructions for the work with beryllium compounds: Naglav, D.; Buchner, M. R.; Bendt, G.; Kraus, F.; Schulz, S., Angew. Chem, DOI: 10.1002/anie.201601809R1; Angew. Chem. Int Ed., 10.1002/ange.201601809R1

[35] Appel, R.; Ruppert, I. Z. Anorg. Allg. Chem. 1974, 406, 131144.

[36] Gilman, H.; Schulze F. J. Chem. Soc. 1927, 2663-2669.

[37] a) Sheldrick, G. M. Acta Crystallogr. 1990, A46, 467-473; b) Sheldrick, G. M. SHELXL-2014, Program for the Refinement of Crystal Structures University of Göttingen, Göttingen (Germany) 2014. (see also: Sheldrick, G. M. Acta Crystallogr. 2008, A64, 112122); c) shelXle, A Qt GUI for SHELXL, Hübschle, C. B.; Sheldrick, G. M.; Dittrich, B. J. Appl. Cryst. 2011, 44, 1281-1284.

Bis(diphenylphosphinimino)methanide and bis(diphenylphosphinimino)methanediide beryllium complexes $\left[\mathrm{CH}\left(\mathrm{PPh}{ }_{2} \mathrm{~N}-2,6-\right.\right.$ $i$ - $\left.\left.\mathrm{Pr}_{2} \mathrm{C}_{6} \mathrm{H}_{3}\right)_{2}\right] \mathrm{BeEt}$ 1, $\left[\mathrm{C}\left(\mathrm{PPh}_{2} \mathrm{NSiMe}_{3}\right)_{2}\right](\mathrm{BeEt})_{2} \mathbf{2}$ and $\left[\mathrm{C}\left(\mathrm{PPh}_{2} \mathrm{NPh}\right)_{2}\right](\mathrm{BeEt})_{2} \mathbf{3}$ were synthesized by reactions of bis(diphenylphosphinimino)methanes $\mathrm{H}_{2} \mathrm{C}\left[\mathrm{PPh}_{2} \mathrm{NR}\right]_{2}$ with different amounts of $\mathrm{BeEt}_{2}$ and characterized by (heteronuclear) NMR and IR spectroscopy as well as by single crystal X-ray diffraction.

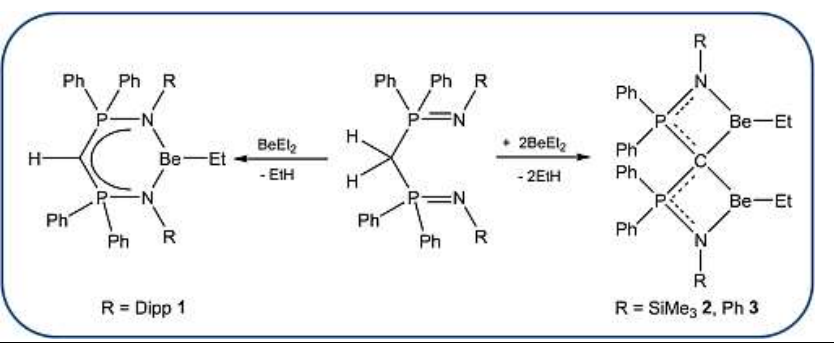




\section{DuEPublico}

This text is made available via DuEPublico, the institutional repository of the University of Duisburg-Essen. This version may eventually differ from another version distributed by a commercial publisher.

\section{DOI: $\quad$ 10.1021/acs.organomet.6b00380}

URN: urn:nbn:de:hbz:464-20201204-121650-1

This document is the Accepted Manuscript version of a Published Work that appeared in final form in: Organometallics 2016, 35, 14, 2378-2383, copyright (C) American Chemical Society after peer review and technical editing by the publisher. To access the final edited and published work see: https://doi.org/10.1021/acs.organomet.6b00380

All rights reserved. 